\title{
Interspecific differences among meiobenthic copepods in the use of microalgal food resources
}

\author{
Margaret C. Pace, Kevin R. Carman* \\ Department of Zoology and Physiology, Louisiana State University, Baton Rouge, Louisiana 70803-1725, USA
}

\begin{abstract}
We examined the potential for interspecific differences among meiobenthic copepods in their exploitation of microalgal food resources in a natural benthic community. The feeding behaviors of Coullana sp., Cletocamptus deitersi, Microarthridion littorale, and Pseudostenhelia wellsi were examined using ${ }^{14} \mathrm{C}$-radiotracer grazing experiments and gut-pigment analyses. In one grazing experiment, laboratory-cultured microalgae were labeled using $\mathrm{NaH}^{14} \mathrm{CO}_{3}$ and injected into intact sediment cores to determine whether copepods were grazing on algae from the water column and/or at the sediment-water interface. In another grazing experiment, $\mathrm{NaH}^{14} \mathrm{CO}_{3}$ was injected directly into sediment cores and grazing on ${ }^{14} \mathrm{C}$-labeled natural algae was measured. Fluorometric analyses of gutpigments were used to determine the recent feeding histories of copepods. Functional responses of copepod feeding to variation in sedimentary chlorophyll (chl) a concentrations were also used to discern interspecific differences in feeding. Coullana sp. grazed on microalgae from the water-column and at the sediment-water interface. C. deitersi grazed predominantly on microalgae from the sediment-water interface. Grazing on laboratory-cultured algae was minimal in $M$. littorale and $P$. wellsi, but grazing experiments with ${ }^{14} \mathrm{C}$-labeled natural algae and gut-pigment analyses indicated that these copepods grazed on microalgae in the field. However, a positive functional response to chl a concentrations by $M$. littorale and a lack of a functional response by $P$. wellsi suggest that these 2 species exploit algal resources difterently. Collectively, our observations indicate that each copepod species examined exploits microalgal resources differently.
\end{abstract}

KEY WORDS: Meiofauna - Grazing - Microalgae Harpacticoid copepods Cletocamptus deitersi Pseudostenhelia wellsi - Microarthridion littorale · Coullana sp.

\section{INTRODUCTION}

Allocation of available food resources affects the type and number of organisms that may coexist in a given system (Begon et al. 1996). Understanding how food is used by organisms in aquatic systems is thus essential to the study of marine food webs. Harpacticoid copepods constitute an important component of marine food webs, both as consumers (Montagna 1995) and producers (Gee 1989). They are often the most abundant or second most abundant meiofaunal group present and serve as an important food source for macrofauna, as well as many larval and juvenile fish species (McCall \& Fleeger 1995). As consumers, copepods feed on diatoms, phytoflagellates, cyanobacteria,

"Addressee for correspondence.

E-mail: zocarm@lsuvm.sncc.lsu.edu bacteria, fungi, and yeasts (Hicks \& Coull 1983). Evidence of interspecific feeding differences among harpacticoid copepods has been found in laboratory studies (Reiper 1978, 1982, Vanden Berghe \& Bergmans 1981, Chandler 1986) and field studies (Carman \& Thistle 1985, Decho \& Castenholtz 1986, Montagna et al. 1995), suggesting that meiobenthic copepods have different nutritional requirements and utilize available food resources differently. Further, food resources used by copepod species may change ontogenetically (Decho \& Fleeger 1988a), seasonally (Lee et al. 1976), or over shorter time scales such as a tidal cycle (Decho 1988, Souza-Santos et al. 1995). Exploitation of different microbial food sources by copepods has been suggested as an explanation for their spatially and temporally heterogeneous distributions (Lee et al. 1977, Reiper 1984, Carman \& Thistle 1985, Decho \& Castenholz 1986, Decho \& Fleeger 1988b). 
Few studies have addressed how microbial food resources are exploited by natural harpacticoid copepod communities. Field studies (Lee et al. 1977. Carman \& Thistle 1985, Decho \& Castenholz 1986) have provided evidence of interspecific feeding differences among harpacticoid copepods as well as positive spatial correlations between the distribution of copepods and their potential microbial food resources (Decho \& Fleeger 1988b, Blanchard 1991, Montagna et al. 1995). Other field studies (Montagna et al. 1983, Alongi 1988), however, have detected no correlation between harpacticoid copepods and their microbial food resources.

Here, we present the results of research designed to gain insight into the mechanisms of in situ copepod feeding behavior. We tested the hypothesis that the co-occurring meiobenthic harpacticoid copepods Coullana sp., Cletocamptus deitersi Richard, Microarthridion littorale Poppe and Pseudostenhelia wellsi Coull \& Fleeger exploit different microalgal resources. With the exception of Decho (1988), previous studies addressing feeding in these copepod species have been limited to laboratory studies (see 'Materials and Methods'). In order to gain a better understanding of feeding behaviors of copepods in the field, in the present study we examined feeding on benthic and planktonic microalgae by copepods using intact sediments with natural faunal and microalgal assemblages. Several techniques were employed to determine whether copepods were grazing on planktonic or benthic microalgae. Through collective consideration of data obtained by using a variety of techniques, a better understanding of harpacticoid feeding behavior was realized.

\section{MATERIALS AND METHODS}

The study site, located near Cocodrie, Louisiana, USA $\left(30^{\circ} 15^{\prime} \mathrm{N}, 91^{\circ} 21^{\prime} \mathrm{W}\right)$, is a mudflat surrounded by stands of Spartina alterniflora Loisel. Salinity at the site varies between 2 and $26 \mathrm{ppt}$. Tidal fluctuations are small $(0$ to $0.3 \mathrm{~m})$ and water movement is predominately wind driven (Phillips \& Fleeger 1985).

Grazing experiments were performed using minimally disturbed, intact cores of sediment. Core liners were constructed from clear butyrate tubing with a cross-sectional area of $9.6 \mathrm{~cm}^{2}$. Cores were collected at low tide in areas of exposed sediment in May and June 1995. Coullana sp., Cletocamptus deitersi, Microarthridion littorale, and Pseudostenhelia wellsi were the dominant harpacticoid copepod species present at the study site, and these species were chosen to examine natural copepod feeding behavior

Coullana sp. is a semi-sessile burrow dweller and has been described as a suspension feeder (Decho 1986, Chandler \& Fleeger 1987, Decho \& Fleeger 1988b). It feeds by creating a current using its oral appendages, drawing in planktonic algae, detritus, and benthic microalgae that may be near the opening of its burrow (Decho 1986). Cletocamptus deitersi is an epibenthic copepod (Fleeger 1980) that has been shown to graze on benthic diatoms (Decho 1986, 1988). Microarthridion littorale is a mud-dwelling, epibenthic copepod (Palmer \& Coull 1980, Morris \& Coull 1992) that can consume benthic as well as planktonic diatoms (Decho 1986). Pseudostenhelia wellsi is a mucus-tube dweller whose feeding biology is unknown. It has not been seen foraging outside of its tube and no feeding current has been observed (Chandler \& Fleeger 1984). It has been hypothesized that $P$. wellsi 'gardens' microbial organisms on the walls of its mucus tube and feeds on these microbes (Chandler \& Fleeger 1984, 1987).

Labeled microalgal grazing experiments. Copepod feeding on benthic versus planktonic microalgae was examined by adding ${ }^{14} \mathrm{C}$-cultured microalgae $\left({ }^{14} \mathrm{C}\right.$ $\mathrm{CM}$ ) to the overlying water or sediment of cores. For all grazing experiments, cores were collected from the study site and overlying water was adjusted to $2 \mathrm{~cm}$ above the sediment surface. Cores were placed under artificial light for the duration of the $4 \mathrm{~h}$ incubation. A $500 \mu$ syringe (Hamilton) was used to administer ${ }^{14} \mathrm{C}$-CM to the sediment surface or overlying water of intact sediment cores. Algae added to the sediment surface were administered through a silicon-sealed port located in the side of each core. Algae added to the overlying water of cores were added from the top of the core. Two diatom species, Thalassiosira weissflogii, a planktonic diatom common to Louisiana salt marshes, Amphora coffeaeformis, a benthic diatom similar in size to $T$. weissflogii, and a dinoflagellate, Isochrysis galbana, were used as food.

An experiment was performed to determine if microalgae injected into the overlying water of cores remained in suspension and, thus, were appropriate for use as indicators of planktonic feeding. ${ }^{14} \mathrm{C}$-labeled Thalassiosira weissflogii, Amphora coffeaeformis, and Isochrysis galbana in $1 \mathrm{ml}$ of artificial sea water, were injected into the overlying water of cores ( 5 cores per algal species). At $0,1,2,3$, and $4 \mathrm{~h}$, a $1 \mathrm{ml}$ aliquot of overlying water was collected from each core and assayed for radioactivity to determine the proportion of algal cells that had settled from the water during the experimental period.

For grazing experiments, sediment cores were collected from the study site and returned to the laboratory. After a $1 \mathrm{~h}$ settling period, $1 \mathrm{ml}{ }^{14} \mathrm{C}$-labeled Thalassiosira weissflogii $\left(2.5 \times 10^{6}\right.$ cells, $\left.1.8 \mathrm{dpm} \mathrm{cell}^{-1}\right)$ were injected into the overlying water of 5 cores ( $T$. weissflogii water experiment). In an additional 5 cores, $500 \mu \mathrm{l}$ of ${ }^{14} \mathrm{C}$-labeled Amphora coffeaeformis (2.5 $\times$ $10^{6}$ cells, $0.38 \mathrm{dpm} \mathrm{cell}^{-1}$ ) was injected onto the sedi- 
ment surface (A. coffeaeformis sediment experiment). Killed controls were injected with labeled cells followed by an injection of $500 \mu 37 \%$ formaldehyde. Five replicates for each algal species were performed. Controls for position of food (water or sediment) and algal species ( $T$ weissflogii or $A$. coffeaeformis) were performed in an additional set of grazing experiments. Treatments were as described above, except that $T$. weissflogii, the planktonic diatom, was injected onto the sediment surface of 5 cores ( $T$. weissflogii sediment experiment) and $A$. coffeaeformis, the benthic diatom, was injected into the overlying water of 5 cores $(A$. coffeaeformis water experiment). Killed controls were repeated as above. Data were expressed as algal cells consumed / $\mu \mathrm{g}$ copepod dry weight/ $4 \mathrm{~h}$.

Grazing experiments using the dinoflagellate Isochrysis galbana (I. galbana water experiment) were also performed. Live I. galbana are motile and do not remain at the sediment surface. This alga was injected only into the overlying water of cores and served as an indicator of planktonic grazing. Sediment cores were collected as described above and $1 \mathrm{ml}{ }^{14} \mathrm{C}$-labeled $I$. galbana $\left(1.26 \times 10^{7}\right.$ cells, $\left.0.37 \mathrm{dpm} \mathrm{cell}{ }^{-1}\right)$ was injected into the overlying water of 5 cores. Killed controls were performed as above. Cores were incubated for $4 \mathrm{~h}$ under artificial light and then harvested.

Cores from all grazing experiments were harvested by collecting the top $2 \mathrm{~cm}$ of sediment and preserving it in $4 \%$ (final concentration) formaldehyde. Samples were stained with rose bengal, and copepod species were separated and enumerated. Ten adult female copepods of each species, when available, were collected from cores and placed into scintillation vials. No fewer than 4 individuals of a species were used in each assay. Copepods were solubilized in $200 \mu$ of TS- 2 tissue solubilizer (Research Products International, Mount Prospect, IL, USA) and incubated overnight at $60^{\circ} \mathrm{C}$ on a slide warmer, after which $100 \mu \mathrm{l}$ of $1.2 \mathrm{~N} \mathrm{HCl}$ was added to neutralize the tissue solubilizer. BioSafe II liquid scintillation cocktail (Research Products International) was added and samples were assayed for radioactivity using a Beckman LS 6000IC liquid scintillation counter (Beckman Instruments, Fullerton, CA, USA). Quenching was corrected for using external standards.

Grazing on ${ }^{14} \mathrm{C}$-labeled natural microalgae. Copepod grazing on ${ }^{14} \mathrm{C}$-natural microalgae $\left({ }^{14} \mathrm{C}-\mathrm{NM}\right)$ was measured in sediment cores collected from the study site in May and June 1995. Cores were injected with $50 \mu \mathrm{Ci} \mathrm{NaH}{ }^{14} \mathrm{CO}_{3}$ following the injection technique described by Carman et al. (1989), incubated for $5 \mathrm{~h}$, and harvested as described above. Five cores were incubated in the dark to account for label uptake due to biotic, nonphotosynthetic processes (Montagna 1983, Carman \& Thistle 1985, Carman 1990). Radioactivity in dark controls was subtracted from radio- activity in light treatments to calculate ${ }^{14} \mathrm{C}$ uptake from grazing on photoautotrophs. Data were expressed as $\mathrm{dpm} / \mu \mathrm{g}$ copepod dry weight $/ 5 \mathrm{~h}$.

The $5 \mathrm{~h}$ incubation period for labeled algae and natural algae grazing experiments is longer than the recorded gut-passage time for these copepods (Decho 1988), and thus actual grazing rates were underestimated. We assumed, however, that copepod grazing rates did not change over the experimental period and, thus, that statistical comparisons of grazing rates were appropriate.

Gut-pigment analyses. Copepods used for gutpigment analyses were obtained by collecting the upper 3 to $5 \mathrm{~mm}$ of sediment from exposed areas of the mudflat. Sediment was poured through a $125 \mu \mathrm{m}$ sieve and rinsed with marsh water to remove small sediment particles and concentrate copepods. The concentrate was transferred to a beaker and live copepods were aggregated using a fiber-optic light source. Copepods were removed by aspirating water and a portion of those extracted was immediately frozen in liquid nitrogen. Remaining live copepods were collected, rinsed with filter-sterilized $(0.45 \mu \mathrm{m})$ marsh water (FMW), and transferred to $40 \mathrm{ml}$ FMW. Animals were starved for $36 \mathrm{~h}$, examined microscopically to insure gut clearance, and then frozen in liquid nitrogen.

To determine total gut-pigments in copepod guts [chlorophyll (chl) a and phaeopigment], animals were thawed and sorted into species. For each replicate, 30 adult female copepods were transferred, under subdued lighting, to $6 \mathrm{ml}$ DMSO:acetone (1:1). Samples were sonicated with a Branson Model 450 sonifier for $1 \mathrm{~min}$ at $90 \mathrm{~W}$ and refrigerated overnight. Samples were then centrifuged for $5 \mathrm{~min}$ at $650 \times \mathrm{g}$. Fluorescence was determined using a Turner Model 10 fluorometer before and after acidification with $1.2 \mathrm{~N} \mathrm{HCl}$. Five replicates were performed for each copepod species. The average pigment content of starved copepods was subtracted from values recorded for copepods that were immediately frozen.

Functional responses. In a separate experiment designed to test the influence of hydrocarbons on benthic food webs, grazing by meiofauna was measured using the ${ }^{14} \mathrm{C}$-NM technique (K. R. Carman, J. W. Fleeger \& S. M. Pomarico unpubl.). Microcosms of sediment (15 cm i.d., see Carman et al. 1995) were collected at the study site and transported to the Louisiana Universities Marine Consortium facility in Cocodrie, where they were maintained on wet tables. Microcosms were irrigated with $5 \mu \mathrm{m}$-filtered marsh water via a drip system, and thus very little phytoplankton was available for consumption (Carman et al. unpubl.). Microcosms were maintained in the laboratory for $28 \mathrm{~d}$, during which time the effects of hydrocarbons were examined. Algal biomass and copepod grazing 
rates were determined at $0,7,14$, and $28 \mathrm{~d}$. Here, we report data from control (uncontaminated) microcosms.

Statistical analyses. Data from each experiment were analyzed using a 1-way analysis of variance (ANOVA). In addition, a 2-way ANOVA was performed on data from the gut-pigment analyses and ${ }^{14} \mathrm{C}-\mathrm{NM}$ grazing experiments to test for temporal effects of time $x$ species interactions. Where significant differences were found, pairwise multiple comparisons were performed using Bonferroni's method (alpha = 0.05). Functional responses were examined by linear regression, with grazing rate as the dependent variable and algal biomass as the independent variable. When necessary, data were $\log _{10}$ transformed to meet assumptions of normality and homogeneity of variance.

Dry weights. Copepods were extracted from sediment and frozen in liquid nitrogen. For each of 5 replicates, 40 adult, female Coullana sp., Cletocamptus deitersi, Microarthridion littorale, or Pseudostenhelia wellsi were rinsed in deionized water and transferred to a tared, aluminum weighing dish. Copepods were dried at $55^{\circ} \mathrm{C}$ for $4 \mathrm{~d}$. After drying, copepods were transferred to a desiccator, cooled to room temperature and weighed using a Cahn C-31 microbalance. Average dry weights/copepod for each harpacticoid species were as follows: $3.15 \mu \mathrm{g}$ for Coullana sp., $1.37 \mu \mathrm{g}$ for $M$. littorale, $1.15 \mu \mathrm{g}$ for C. deitersi, and $0.87 \mu \mathrm{g}$ for $P$. wellsi. Dry weights were used to standardize data from grazing experiments.

\section{RESULTS}

\section{Grazing on prelabeled laboratory-cultured microalgae}

The purpose of the ${ }^{14} \mathrm{C}$-CM grazing experiments was to examine differences in benthic and planktonic feeding among copepod species. Planktonic algae, Thalassiosira weissflogii and Isochrysis galbana, added to the overlying water of cores remained in the water column for the duration of the experiment (Fig. 1). Most ( $87 \%$ ) of the benthic alga Amphora coffeaeformis settled to the sediment surface after $1 \mathrm{~h}$. Because $T$. weissflogii and $I$. galband (planktonic microalgae) remained in suspension, feeding on these 2 algae was assumed to be via planktonic feeding. Copepod feeding on $A$. coffeaeformis, the benthic alga which quickly settled out of the water column (Fig. 1), was via benthic grazing. Consumption of $T$. weissflogii and $A$. coffeaeformis added to the sediment was assumed to be from benthic feeding at the sediment-water interface.

Grazing rates differed significantly among copepod species in the ${ }^{14} \mathrm{C}-\mathrm{CM}$ experiments (Table 1 ). Benthic and planktonic feeding by Coullana sp. was greater than other copepod species tested in both the Thalas- siosira weissflogii (Fig. 2) and Isochrysis galbana (Fig. 3) water experiments. Coullana sp. fed on Amphora coffeaeformis at significantly higher rates than all other copepod species in the sediment experiment (Fig. 2). Coullana sp and Cletocamptus deitersi fed on A. coffeaeformis at equivalent rates in the water experiment, and both rates were significantly higher than those of Microarthridion littorale and Pseudostenhelia wellsi

Benthic grazing by Cletocamptus deitersi was also significantly higher than grazing rates of Microarthridion littorale and Pseudostenhelia wellsi in the Thalassiosira weissflogii sediment and Amphora coffeaeformis water experiments (Fig. 2). Benthic grazing rates were not significantly different among these 3 species in the $A$. coffeaeformis sediment experiment.

Grazing experiments using ${ }^{14} \mathrm{C}-\mathrm{CM}$ indicated that Microarthridion littorale and Pseudostenhelia wellsi fed relatively little from the water column. Benthic and planktonic grazing rates of $M$. littorale and $P$. wellsi were not significantly different (Figs. $2 \& 3$ ). In the Thalassiosira weissflogii sediment and Amphora coffeaeformis water experiments, grazing rates of Coullana sp. and Cletocamptus deitersi were significantly higher than $M$. littorale. Lowest overall grazing rates were seen in $P$. wellsi (Figs. $2 \& 3$ ) and its feeding was predominately benthic. Planktonic grazing by $P$. wellsi in the $T$. weissflogii water experiment was not significantly different from killed controls.

\section{Grazing on ${ }^{14} \mathrm{C}$-labeled natural microalgae}

Although our initial goal was to analyze all 4 species using ${ }^{14} \mathrm{C}-\mathrm{CM},{ }^{14} \mathrm{C}-\mathrm{NM}$, and gut pigments, variable

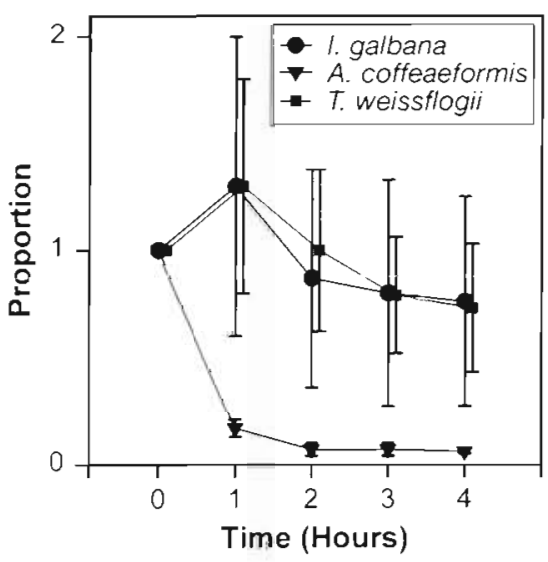

Fig. 1. Isochrysis galbana, Amphora coffeaeformus, Thalassiosira weissflogii. Settlement of algal cells over the experimental period. Error bars are $\pm 1 \mathrm{SD}(\mathrm{n}=4)$. Points are proportion of cells remaining in the water column at each sampling time in relation to time 0 
Table 1 Results of the 1-way ANOVA for copepod feeding behavior experiments. Abbreviations are as follows: ${ }^{14} \mathrm{C}-\mathrm{CM}=$ copepod grazing on laboratory-cultured microalgae; ${ }^{14} \mathrm{C}$-NM = copepod grazing on natural microalgae; gut-content analyses = analysis of copepod total gut-pigments and \% chl $a_{i}$ sed $=$ algae added to the sediment surface of cores; water = algae added to the overlying water of cores; $\mathrm{BIC}=\mathrm{NaH}^{14} \mathrm{CO}_{3}$ labeled natural microalgae; total pigment $=$ total amount of chl a plus phaeopigment in copepod guts; \% chl $a=$ [chlorophyll $a /(\mathrm{chl} a+$ phaeopigment) $] \times 100 \%$

\begin{tabular}{|lccc|}
\hline Source & df & F-value & $\mathrm{p}$ \\
\hline${ }^{14} \mathrm{C}$-CM & & & \\
T. weissflogii sed & 3 & 20.4 & $<0.0001$ \\
T. weissflogii water & 3 & 22.4 & $<0.0001$ \\
A. coffeaeformis sed & 3 & 5.84 & 0.017 \\
A. coffeaeformis water & 3 & 16.4 & $<0.0001$ \\
I. galbana water & 2 & 14.3 & 0.0009 \\
${ }^{14} \mathrm{C}-\mathrm{NM}$ & & & \\
BIC (May) & 3 & 11.3 & 0.0021 \\
BIC (June) & 2 & 1.85 & 0.22 \\
Gut-content analyses & & & \\
Total pigment (May) & 2 & 3.34 & 0.02 \\
Total pigment (June) & 2 & 2.13 & 0.15 \\
\% chl a (May) & 2 & 5.99 & 0.04 \\
\% chl a (June) & 2 & 2.17 & 0.16 \\
\hline
\end{tabular}

abundances of Cletocamptus deitersi and Microarthridion littorale prevented us from being able to do so. In both May and June, we were unable to collect a sufficient number of $M$. littorale for pigment analysis. In June, $C$. deitersi were not present in cores used for ${ }^{14} \mathrm{C}-\mathrm{CM}$.

The purpose of ${ }^{14} \mathrm{C}$-NM grazing experiments was to measure copepod grazing on the natural microalgal

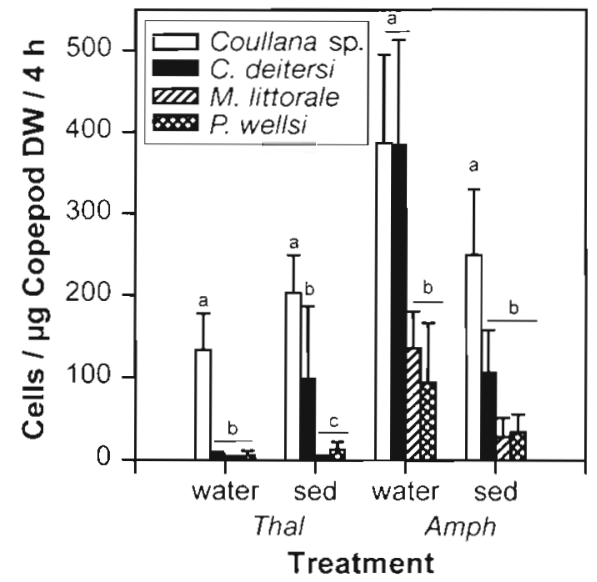

Fig. 2. Coullana sp., Cletocamptus deitersi, Microarthridion littorale, Pseudostenhelia wellsi. Harpacticoid grazing on ${ }^{14} \mathrm{C}$-labeled Thalassiosira weissflogi (Thal) and Amphora coffeaeformis (Amph) added to the water (water) or sediment (sed) $\left({ }^{i 4} \mathrm{C}-\mathrm{CM}\right)$. Different letters indicate significant differences among species. Horizontal bars are mean cells/ $\mathrm{gg}$ copepod dry weight (DW). Error bars are $+1 \mathrm{SD}(\mathrm{n}=5)$ assemblage. In the May grazing experiment (Fig. 4A), dark controls accounted for an average of $112 \%$ of the label in Coullana sp., and 0.83, 29 and 16\% of label in Cletocamptus deitersi, Pseudostenhelia wellsi, and Microarthridion littorale, respectively. Dark controls in the June experiment (Fig. 4B) accounted for 45, 9, 3, and $32 \%$ of the label in Coullana sp., C. deitersi, M. littorale, and $P$. wellsi, respectively.

Grazing rates on ${ }^{14} \mathrm{C}$-NM were significantly different among copepod species in May but not June (Table 1). Grazing rates of Cletocamptus deitersi collected in May were significantly higher than those of Coullana sp. (Fig. 4A). Grazing rates of Microarthridion littorale and Pseudostenhelia wellsi in May were not significantly different from grazing rates of Coullana sp. or $C$. deitersi. In May, $C$. deitersi grazed at a rate more than double that of $M$. littorale and $P$. wellsi, though the difference was not significant, probably due to low sample size. In contrast to the May experiment, grazing in June by Coullana sp. was higher than that of $M$. littorale and $P$. wellsi, though the 1 -way ANOVA detected no significant differences in grazing rates among species (Fig. 4B, Table 1). A 2-way ANOVA revealed that grazing rates by Coullana sp. in May and June were significantly different (Table 2). Grazing rates in the other copepod species were not significantly different between May and June, and there were no significant time $\times$ species interactions.

\section{Gut-pigment analyses}

Total gut-pigment levels were significantly higher in Pseudostenhelia wellsi than in Cletocamptus deitersi

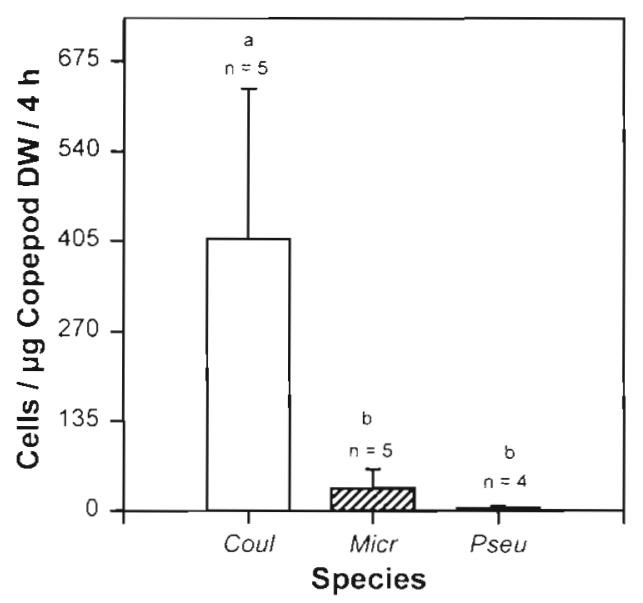

Fig. 3. Harpacticoid grazing on ${ }^{14} \mathrm{C}$-labeled Isochrysis galbana $\left({ }^{14} \mathrm{C}-\mathrm{CM}\right)$. Species designations are as follows: Coul = Coullana sp., Micr $=$ Microarthridion littorale, $P_{s e u}=P_{\text {seudo }}$. stenhelia wellsi. Different letters indicate significant differences among species. Error bars are $+1 \mathrm{SD}$ 


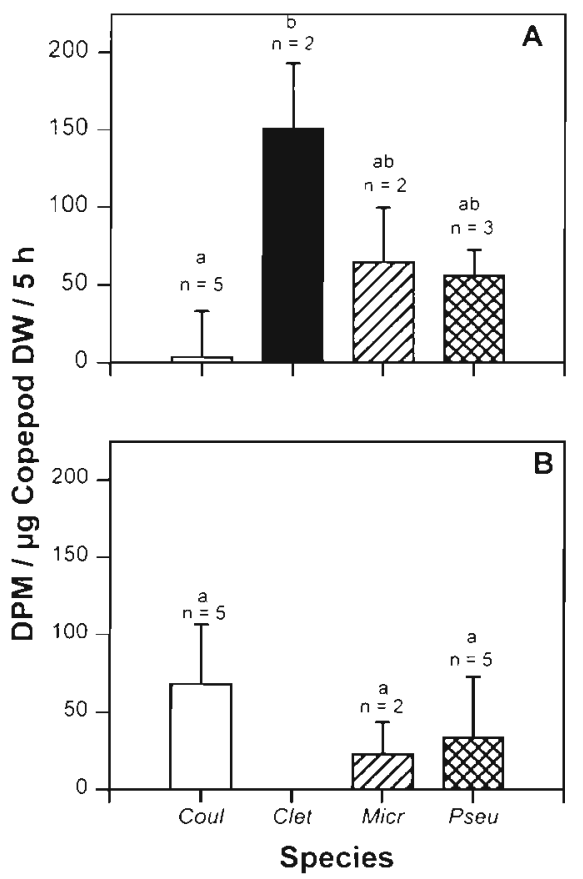

Fig. 4. (A) May and (B) June $1995{ }^{14} \mathrm{C}$-natural microalgae $\left({ }^{14} \mathrm{C}-\mathrm{NM}\right)$ grazing experiment results. Abbreviations are as follows: Coul $=$ Coullana sp., Clet $=$ Cletocamptus deitersi, Micr = Microarthridion littorale, $P_{\text {seu }}=$ Pseudostenhelia wellsi. Different letters indicate significant differences among species. Error bars are $+1 \mathrm{SD}$

and Coullana sp. for May samples (Fig. 5A, Table 1). Total gut-pigment levels were not significantly different in Coullana sp., C. deitersi, and $P$. wellsi collected in June (Fig. 5B, Table 1). A 2-way ANOVA revealed that over May and June total pigment in $P$. wellsi was significantly higher than in $C$. deitersi and Coullana sp. (Table 2).

Percent chl a detected in the guts of Coullana sp., Cletocamptus deitersi, and Pseudostenhelia wellsi collected in May were significantly different; although the pattern of interspecific differences was similar in June, \% chl a did not differ significantly among species

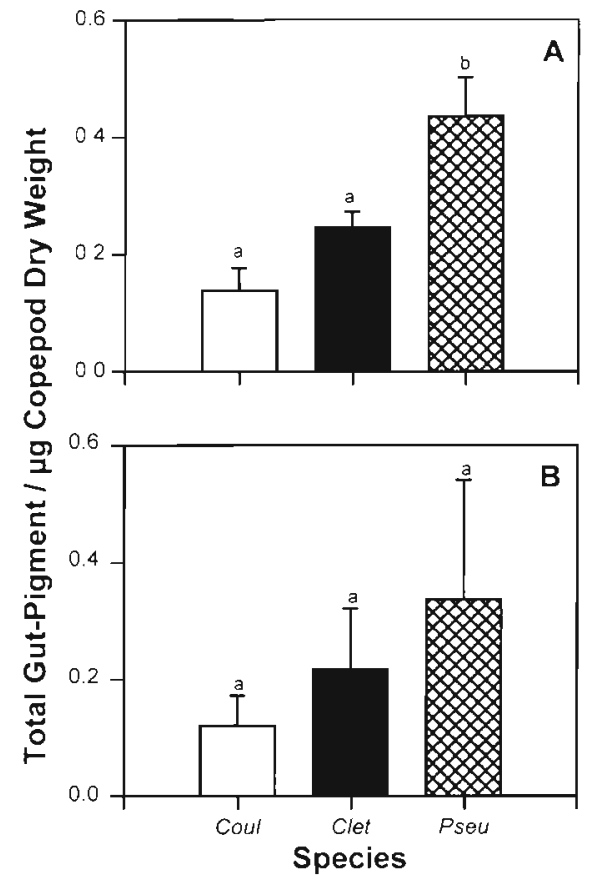

Fig. 5. Total gut-pigment/ $\mu$ g copepod dry weight for animals collected in (A) May and (B) June 1995. Total gut-pigment is defined as the sum of chl a and phaeopigment. Abbreviations are as follows: Coul $=$ Coullana sp., Clet $=$ Cletocamptus deit ersi, Pseu $=$ Pseudostenhelia wellsi. Different letters indicate significant differences among species. Error bars are $+1 \mathrm{SD}$ $(\mathrm{n}=5)$

(Table 1, Fig. 6). A. 2-way ANOVA revealed that over May and June \% chl $a$ in $P$. wellsi was significantly lower than in $C$. deitersi and Coullana sp. (Table 2).

\section{Functional responses}

Benthic microalgal biomass in control microcosms varied from 1.02 to $7.25 \mu \mathrm{g} \mathrm{chl} \mathrm{a} \mathrm{cm}^{-2}$ over the $28 \mathrm{~d}$ experiment. Relationships between microalgal biomass and grazing rates of the 4 copepod species con-

Table 2. Results of a 2-way ANOVA analyzing copepod grazing experiments in May and June 1995. Abbreviations are as follows: gutpigments = total gut-pigments; \% chl a $=[\mathrm{chl} \mathrm{a} /(\mathrm{chl} a+$ phaeopigment $)] \times 100_{i}{ }^{14} \mathrm{C}-\mathrm{NM}=$ copepod grazing on natural microalgae

\begin{tabular}{|llcc|}
\hline Assay & Factor & $p$ & A posteriori \\
\hline Gut-pigments & Species & $<0.001$ & P. wellsi $>$ C. deitersi and Coullana sp. \\
& Month & 0.078 & \\
\% chl a & Species $\times$ Month & 0.350 & P. wellsi $<$ C. deitersi and Coullana sp. \\
& Species & 0.005 & \\
${ }^{14} \mathrm{C}-\mathrm{NM}$ & Month & 0.087 & June Coullana sp. > May Coullana sp. \\
& Species $\times$ Month & 0.719 & \\
& Species & 0.810 & \\
\hline
\end{tabular}




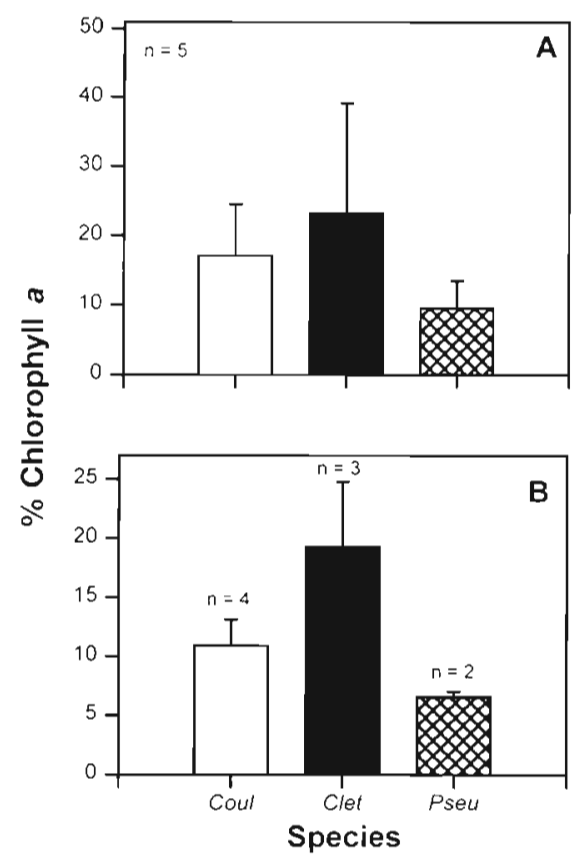

Fig. 6. Chl $a$ as a percent of total gut-pigment (chl $a$ and phaeopigment) in harpacticoid species collected in (A) May and (B) June 1995. Abbreviations are as follows: Coul = Coullana sp., Clet $=$ Cletocamptus deitersi, Pseu $=$ Pseudostenhelia wellsi. Error bars are $+1 \mathrm{SD}$

sidered here are presented in Fig. 7. Significant positive functional responses to algal abundance were detected for Microarthridion littorale and Cletocamptus deitersi, but not Pseudostenhelia wellsi or Coullana sp.

\section{DISCUSSION}

The purpose of this study was to determine whether interspecific differences in the use of microalgal food resources existed among co-occurring harpacticoid copepods in saltmarsh sediments. Our data suggest that although all 4 copepod species studied grazed on microalgae, feeding patterns differed among species. Different assays of grazing yielded different types of information, and sometimes qualitatively different results.

${ }^{14} \mathrm{C}-\mathrm{CM}$ grazing experiments illustrated potential interspecific differences in benthic versus planktonic feeding, and suggested that overall microalgal grazing by Microarthridion littorale and Pseudostenhelia wellsi was relatively low (Figs. 2 \& 3). Coullana sp. grazed effectively on planktonic and benthic algae and was especially effective at consuming algae at the sediment-water interface. Cletocamptus deitersi grazed predominantly at the sediment surface (Fig. 2) and its
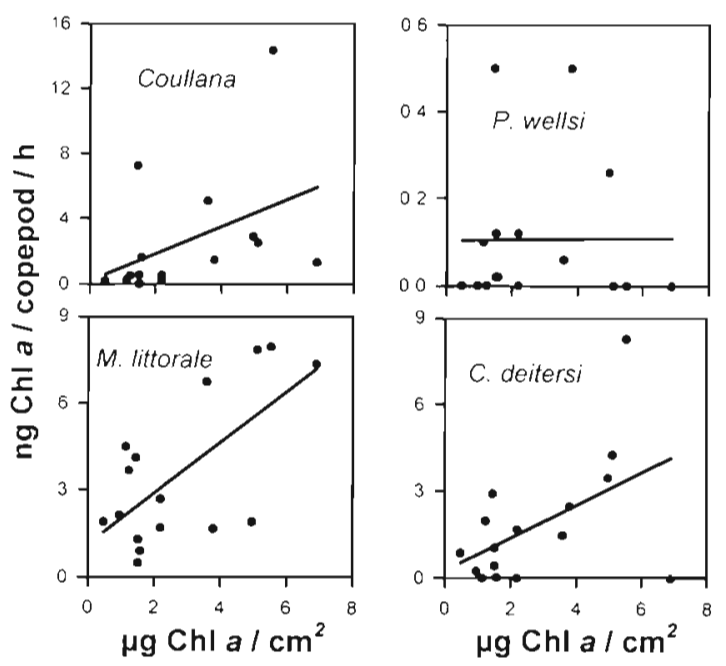

Fig. 7. Functional responses of copepod grazing to variability in benthic chl $a$. Lines are best fit linear regressions. Regression statistics, where $y=\mu \mathrm{g}$ chl a consumed, are as follows Coullana sp.: $y=0.0009+\left(0.0042 \times \mu \mathrm{g}\right.$ chl a $\left.\mathrm{cm}^{-2}\right) \cdot \mathrm{r}^{2}=$ $0.181, \mathrm{p}=0.1134 ;$ Pseudostenhelia wellsi: $y=0.0005+$ $\left(0.000005 \times \mu \mathrm{gchl} a \mathrm{~cm}^{-2}\right), \mathrm{r}^{2}=0.0001, \mathrm{p}=0.9650 ;$ Microarthridion littorale: $y=0.0055+\left(0.00443 \times \mu \mathrm{g} \mathrm{chl} \mathrm{a} \mathrm{cm}^{-2}\right)$ $\mathrm{r}^{2}=0.442, \mathrm{p}=0.0049 ;$ Cletocamptus deitersi: $y=0.00128+$ $\left(0.00283 \times \mu \mathrm{g} \mathrm{chl} \mathrm{a} \mathrm{cm}^{-2}\right), \mathrm{r}^{2}=0.256, \mathrm{p}=0.0455$

benthic grazing rates were comparable to Coullana sp.; it was not, however, an effective plankton feeder. $M$. littorale and $P$. wellsi were almost completely ineffective at consuming planktonic algae and consumed benthic microalgae at lower rates than did $C$. deitersi or Coullana sp. (Figs. $2 \& 3$ ).

Laboratory studies by Decho (1986) examined benthic and planktonic feeding by Coullana sp., Cletocamptus deitersi, and Microarthridion littorale on diatoms (Thalassiosira weissflogii and Amphora tenerrina) in azoic sediments, and feeding experiments were conducted separately for each species. Thus, copepods in Decho's (1986) experiments did not interact with other meiofaunal species and fed only on introduced algal food. Our experiments, involving the addition of ${ }^{14} \mathrm{C}$-labeled benthic and planktonic algae, were similar to those of Decho (1986), except they were conducted using natural sediments with their resident meiofaunal and microalgal communities intact. Data presented here are consistent with Decho's (1986) conclusions that Coullana sp. is an effective plankton feeder and $C$. deitersi feeds at the sedimentwater interface, but our observation that Coullana sp. also feeds effectively on benthic microalgae differs from that of Decho (1986). It is possible that grazing by Coullana sp. in natural sediments (this study) differs from its grazing behavior in azoic sediment (Decho 1986). 
Our observations of Microarthridion littorale grazing also differed from the results of Decho (1986) who found $M$. littorale to graze on planktonic and benthic algae at rates similar to or higher than Coullana sp. Other studies involving $M$. littorale have strongly implicated it as a consumer of benthic microalgae (Decho 1988, Souza-Santos et al. 1995). Further, ${ }^{14} \mathrm{C}$ NM assays of feeding behavior (discussed below) indicated consumption of benthic microalgae by $M$. littorale

In this study, natural microalgae as well as ${ }^{14} \mathrm{C}$-CM were present in intact sediment cores and Microarthridion Iittorale could have fed on a natural algal source and not on the laboratory-cultured algae. One limitation of the ${ }^{14} \mathrm{C}$-CM technique is that only grazing on the introduced ${ }^{14} \mathrm{C}$-labeled microalgae can be measured while grazing on unlabeled species is not accounted for; the offered ${ }^{14} \mathrm{C}$-labeled algae may be preferentially consumed or avoided by copepods, leading to over- or underestimation of actual copepod grazing rates.

Gut-pigment analyses as well as grazing experiments using ${ }^{14} \mathrm{C}-\mathrm{NM}$ indicated that copepods grazed on algae in the field, but the 2 methods yielded qualitatively different results. The ${ }^{14} \mathrm{C}-\mathrm{NM}$ method indicated that grazing by Coullana $\mathrm{sp}$. (but not other species) was affected by tidal exposure, but gut pigments did not vary with tidal exposure for any of the copepods analyzed. Previous studies indicate that tidal cycle and presence or absence of water overlying the sediment surface may affect copepod grazing rates (Decho 1986, 1988, Souza-Santos et al. 1995). In both May (late low water) and June (early low water), Coullana sp. gut-pigments were lower than in Cletocamptus deitersi and Pseudostenhelia wellsi (Fig. 5). The ${ }^{14} \mathrm{C}$-NM method, however, showed that in May grazing by Coullana sp. was greatly reduced compared to other species (Fig. 4A), and that the grazing rate of $C$. deitersi was more than double that of the other copepod species; in June, however, Coullana sp. grazing was higher than in other species (Fig 4B). Further, $P$. wellsi gut-pigments were highest in both May and June samplings, but grazing determined by ${ }^{14} \mathrm{C}-\mathrm{NM}$ was intermediate at both times. Thus, interspecific and temporal variation in gut-pigments and grazing rates determined from ${ }^{14} \mathrm{C}$ - NM seem to be largely independent of each other. Nevertheless, the dramatic difference in ${ }^{14}$ C - NM grazing rates observed for Coullana sp. in May and June is intriguing. Coullana sp. tends to occupy a subtidal habitat and is not often exposed at low tide, while the other copepod species are intertidal and exposed more frequently. A field study by Decho (1988) examined grazing of Coullana sp. (and other species) at high water, early low water, and late low water using gut-pigment analysis. Decho (1988) observed that grazing by Coullana sp. was highest at early low water and lowest at late low water. Decho (1988) suggested that inability to feed on plankton at late low water caused the reduced feeding by Coullana sp., and our ${ }^{14} \mathrm{C}-\mathrm{NM}$ observations would appear to support that conclusion. However, Decho's (1988) grazing rates were calculated based on gut-pigment measurements, which did not vary with sediment exposure in our study.

There are no previous laboratory or field grazing studies for Pseudostenhelia wellsi against which we can compare our observations. It has been suggested, however, that $P$. wellsi grazes on bacteria gardened on the inner walls of its mucus tube (Chandler \& Fleeger 1984). Morphological and physiological similarities between $P$. wellsi and Diarthrodes nobilis, a phytal copepod presumed to garden bacteria on its mucus capsule (Hicks \& Grahame 1979), are also consistent with the hypothesis that $P$. wellsi gardens its food (Williams-Howze et al. 1987). Our data indicate, however, that $P$. wellsi feeds on nonplanktonic algae to at least some degree as relatively high amounts of gut pigments and moderate ${ }^{14} \mathrm{C}$-NM grazing rates were detected. In principle, $P$. wellsi could feed on sedimentary algae or algae growing in its tube. If it does not leave its burrow or create a feeding current, grazing on labeled algae in the ${ }^{14} \mathrm{C}$-NM experiments by $P$. wellsi would have been restricted to algal cells that settled into its mucus tube, which could explain the low grazing rates by $P$. wellsi observed in the ${ }^{14} \mathrm{C}$-CM grazing experiments. ${ }^{14} \mathrm{C}$ label consumed by $P$. wellsi in the ${ }^{14} \mathrm{C}$-NM grazing experiments may have resulted from the labeling of algae growing on the inner walls of its mucus tube. In contrast to Coullana sp., grazing rates of $P$. wellsi were seemingly unaffected by the extreme low tide observed in May. If this copepod were grazing on organisms growing on the inner walls of its mucus tube, grazing rates during an extreme low tide would presumably be unaffected. While the presence of pigment in the guts of $P$. wellsi indicated that it was consuming algal material, the small fraction of $P$. wellsi gut-pigment that was in the form of chl a suggested that $P$. wellsi was ingesting predominantly detrital plant material or that digestion efficiency in $P$. wellsi was high relative to other copepod species.

Another means of examining feeding is to determine the relationships of grazers with their putative food source. If grazers are limited by food availability, grazing rates should increase with increasing food concentration (Karrh \& Miller 1994). Significant functional responses by Microarthridion Iittorale and Cletocamptus deitersi, but not Coullana sp. or Pseudostenhelia wellsi provided further evidence of dietary differentiation among copepod species. Specifically, they indicate that $M$. littorale and $C$. deitersi feeding rates are 
closely linked to the availability of benthic microalgae, but that $P$. wellsi and Coullana sp. are more dependent on other food sources such as planktonic algae and/or detritus.

Blanchard (1991) reported that meiofaunal grazing on microphytobenthos exceeded production, and suggested that this relationship could lead to food limitation for meiofauna. Montagna et al. (1995) observed that increases in meiofaunal grazing rates (microalgal biomass consumed per individual) were correlated with high biomass of microphytobenthos. Both studies (Blanchard 1991, Montagna et al. 1995) considered meiofaunal grazing at the level of taxon (e.g. harpacticoids, nematodes, and ostracods). Our observations concerning functional relationships between meiofauna and microalgae are consistent with those of Montagna et al. (1995), but demonstrate that the functional response of individual species varies considerably. Thus, consideration of species composition may be necessary to accurately characterize and predict meiofaunal-microphytobenthos interactions.

Overall, various lines of evidence indicate that interspecific feeding differences exist among the harpacticoid copepods examined in this study. While Coullana sp. grazed on both benthic and planktonic diatoms, its reduced feeding activity in response to prolonged exposure of the sediment, as well as its weak functional response to benthic algal biomass, suggest that its diet is derived primarily from planktonic material, which is generally consistent with the observations of Decho $(1986,1988)$. Cletocamptus deitersi grazed predominantly on benthic diatoms and fed at high rates even after prolonged exposure of the sediment. These observations, in conjunction with a significant functional response to benthic algal biomass, strongly implicate benthic algae as its primary food source (Decho 1988). While field data show that Pseudostenhelia wellsi consumes algae (high gut-pigment content and moderate ${ }^{14} \mathrm{C}-\mathrm{NM}$ grazing rates), the inability of $P$. wellsi to consume labeled $\left({ }^{14} \mathrm{C}\right.$-CM) planktonic algae, and the fact that prolonged tidal exposure did not influence feeding (in contrast to Coullana sp.), suggest that it does not feed on plankton. The very low consumption of added benthic prelabeled $\left({ }^{14} \mathrm{C}-\mathrm{CM}\right)$ algae, combined with the lack of a functional response to benthic algal biomass, is consistent with the hypothesis that $P$. wellsi feed on algal material growing in their tubes. Clearly, further work is needed to determine the factors influencing the feeding biology of $P$. wellsi. Data for Microarthridion littorale are incomplete and equivocal, especially given that previous studies have strongly implicated $M$. littorale as a feeder on benthic and planktonic algae. The lack of feeding on algae in the ${ }^{14} \mathrm{C}$-CM experiment may have occurred because of dietary selectivity; at a minimum, however, the ${ }^{14} \mathrm{C}-\mathrm{CM}$ experiment illustrates that $M$. littorale feeding preferences differ from those of Coullana sp. and $C$. deitersi. Field data $\left({ }^{14} \mathrm{C}-\mathrm{NM}\right)$ indicate that $M$. littorale does feed on microalgae, and that feeding is relatively unaffected by prolonged exposure of the sediment. The significant functional response of $M$. littorale to benthic microalgal biomass implicates benthic algae as an important resource, and differentiates its feeding from that of $P$. wellsi.

Interspecific differences in the use of microalgal resources suggests that food-resource partitioning may occur among these 4 copepod species. By definition, resource partitioning implies that the partitioned resource is limiting (Begon et al. 1996), and we did not examine food limitation in this study. We suggest, however, that consideration of food limitation among meiofaunal species would be an important topic for future studies.

Acknowledgements. C. Gregg, J. Gregg, G. Lotufo, and S Pomarico assisted with field and laboratory experiments Copepod dry weights were determined using facilities in the laboratory of $M$. Dagg. The manuscript was improved by comments from J. Fleeger and P. LaRock. The research was supported in part by a grant from the Office of Naval Research (No0014-93-1-0975)

\section{LITERATURE CITED}

Alongi DM (1988) Microbial-meiofaunal interrelationships in some tropical intertidal sediments. J Mar Res 46:349-365

Begon M, Harper JL, Townsend CR (1996) Ecology, 3rd edn Blackwell Science Ltd, Oxford

Blanchard GF (1991) Measurements of meiofauna grazing rates on microphytobenthos: is primary production a limiting factor? J Exp Mar Biol Ecol 147:37-46

Carman KR (1990) Mechanisms of uptake of radioactive labels by meiobenthic copepods during grazing experiments. Mar Ecol Prog Ser 68:71-83

Carman KR, Dobbs FC, Guckert JB (1989) Comparison of three techniques for administering radiolabeled substrates to sediments for trophic studies: uptake of label by harpacticoid copepods. Mar Biol 102:119-125

Carman KR, Fleeger JW, Means JC, Pomarico SM, MCMillin DJ (1995) Experimental investigation of the effects of polynuclear aromatic hydrocarbons on an estuarine sediment food web. Mar Environ Res 40:289-318

Carman KR, Thistle D (1985) Microbial food partitioning by three species of benthic copepods. Mar Biol 88:143-148

Chandler GT (1986) High-density culture of meiobenthic harpacticoid copepods within a muddy sediment substrate. Can J Fish Aquat Sci 43:53-59

Chandler GT, Fleeger JW (1984) Tube-building by a marine meiobenthic harpacticoid copepod. Mar Biol 82:15-19

Chandler GT, Fleeger JW (1987) Facilitative and inhibitory interactions among estuarine meiobenthic harpacticoid copepods. Ecology 68:1906-1919

Decho AW (1986) Water-cover influences on diatom ingestion rates by meiobenthic copepods. Mar Ecol Prog Ser 33 139-146

Decho AW (1988) How do harpacticoid grazing rates differ 
over a tidal cycle? Field verification using chlorophyllpigment analyses. Mar Ecol Prog Ser 45:263-270

Decho AW, Castenholz RW (1986) Spatial patterns and feeding of meiobenthic harpacticoid copepods to resident microbial flora. Hydrobiologia 131:87-96

Decho AW, Fleeger JW (1988a) Ontogenetic feeding shifts in the meiobenthic harpacticold copepod Nitocra lacustris. Mar Biol 97:191-197

Decho AW, Fleeger JW (1988b) Microscale dispersion of meiobenthic copepods in response to food-resource patchiness. J Exp Mar Biol Ecol 118:229-243

Fleeger JW (1980) Community structure of an estuarine meiobenthic copepod assemblage. Estuar Coast Mar Sci 10: $107-118$

Gee JM (1989) An ecological economic review of meiofauna as food for fish. Zool J Linn Soc 96:243-261

Hicks GRF, Coull BC (1983) The ecology of marine meiobenthic harpacticoid copepods. Oceanogr Mar Biol Annu Rev 21:67-175

Hicks GRF, Grahame J (1979) Mucus production and its role in the feeding behavior of Diarthrodes nobilis (Copepoda: Harpacticoida), J Mar Biol Ass UK 59:321-330

Karrh RR, Miller DC (1994) Functional response of a surface-deposit feeder Saccoglossus kowalevskii. Limnol Oceanogr 39:1455-1464

Lee JJ, Tietjen JH, Garrison JR (1976) Seasonal switching in the nutritional requirements of Nitocra typica, a harpacticoid copepod from salt marsh aufwuchs communities. Trans Am Microse Soc 95(4):627-637

Lee JJ, Tietjen JH, Mastropaolo C, Rubin H (1977) Food quality and the heterogenous spatial distribution of meiofauna. Helgol Meeresunters 30:272-282

McCall JN, Fleeger JW (1995) Predation by juvenile fish on hyperbenthic meiofauna: a review with data on post-larval Leiostomus xanthurus. Vie Milieu 45:61-73

Montagna PA (1983) Live controls for radioisotope tracer food chain experiments using meiofauna. Mar Ecol Prog Ser $12: 43-46$

This article was presented by S. P. Meyers (Senior Editorial Advisor), Baton Rouge, Louisiana, USA
Montagna, PA (1995) Rates of metazoan meiofaunal microbivory: a review. Vie Melieu 45:1-9

Montagna PA, Blanchard GF, Dinet A (1995) Effect of production and biomass of intertidal microphytobenthos on meiofaunal grazing rates. J Exp Mar Biol Ecol 185: $149-165$

Montagna PA, Coull BC, Herring TL, Dudley BW (1983) The relationship between abundances of meiofauna and their suspected microbial food (diatoms and bacteria). Estuar Coast Shelf Sci 17:381-394

Morris JT, Coull BW (1992) Population dynamics, numerical production, and potential predation impact on a meiobenthic copepod. Can J Fish Aquat Sci 49:609-616

Palmer MA, Coull BC (1980) The prediction of development rate and the effect of temperature for the meiobenthic copepod, Microarthridion littorale (Poppe). J Exp Mar Biol Ecol 48:73-83

Phillips FE, Fleeger JW (1985) Meiofauna meso-scale variability in two estuârine habitats. Estuar Coast Shelf Sci 21. $754-756$

Reiper M (1978) Bacteria as food for marine harpacticoid copepods. Mar Biol 45:337-345

Reiper M (1982) Feeding preferences of marine harpacticoid copepods for various species of bacteria. Mar Ecol Prog Ser 7:303-307

Reiper M (1984) Relationships between bacteria and marine copepods. Bacteriol Mar 169-172

Souza-Santos LP, Castel J, Dossantos J (1995) Feeding rate cycle of the epibenthic harpacticoid copepod Harpacticus flexus: laboratory experiments using fecal pellet counts Vie Milieu 45(1):75-83

Van den Berghe W, Bergmans $M$ (1981) Differential food preferences in three co-occurring species of Tisbe (Copepoda, Harpacticoida). Mar Ecol Prog Ser 4:213-219

Williams-Howze J, Silverman H, Fleeger JW (1987) Internal morphology related to tube-building in the meiobenthic copepod Pseudostenhelia wellsi. J Crustacean Biol 7 $171-181$

Manuscript first received: May 30,1996

Revised version accepted: September 3, 1996 